
ponsed United States Atomic Enory Aor United stetes sor the their employes, not any of Commian, nor any of ther or theit amployes, thet contrectors, ubcontroctors, or thet ampioysu, mates any wrranty, exprew of linplied, or awnin conven pabilty of reiponsibity for the accuracy, complaten or unfutive of any information, apparatus,

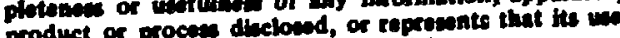
product or proces dinclowed, or ropressise

\title{
ECOLOGICAL CONSIDERATIONS IN REACTOR POWER PLANT SITNG*
}

\author{
S. I. Auerbach, D. J. Nelson, S. V. Kaya, D. E Reichle \\ and C. C. Coutant \\ Ecological Sciences Division \\ Oak Ridge National Laboratory \\ Oak Ridge, Tennesses 37830
}

\section{INTRODUCTION}

The rapidly expanding interest in the utilization of nuclear energy as a power source has started to focus public atiention on the benefits and risks associated with the peaceful uses of the atom. The context of the current concern differs markedly from the last pericd of major public interest in atomic matters which occurred during the period of weapon testing with its associated worldwide radioactive fallout. The current phase happens to be concomitant with a more general concern about environmental quality and with the impact of technology on the environment. As a result of

\footnotetext{
* Research sponsored by the U. S. Atomic Energy Commission under contract with
} the Union Carbide Corporation. 
this concern, objections are being made to the installation of nuclear power stations by conservationists and other environmentally oriented individuals in various parts of the country. The ir objections are based around consistent themes, namely, impoct of radioactivity in the environment, movement of radionuclides through food chains with possible hazard to humans, and effects of thermally hot effluents on the ecology of the region.

Each of these concerns has a basis in, or is related to, some underlying ecological phenomenon. This paper will discuss four ecological considerations which bear on the locotion of nuclear power plants. These are: 1) long-term effects of the releosed radionuclides on the environment, especially on ma intenonce of the ecological balence; 2) environmental fate of radionuclides, including their food chain dynamics and potential to build-up at different ecological levels; 3) ecological pathways by which radionuclides may expose human population groups; and 4) influences of the discharge of waste heat into the aquatic environment.

\section{EFFECTS OF LOW-LEVEL RELEASES TO THE ENVIRONMENT}

In the concern over nuclear power stations the question has been raised whether the radiation resulting from radibactive waste releases at MPC levels would couse ecological problems. Essentially, the question to be addressed is whether the doses that would result from release of radionuclides in accordance with current guidelines would result in demonstrable effects which in turn $m$ ight bear on the location of particular reactor sites.

Since all of the MPC's are derived for internal exposure of man, an obvious question relating to exposure of biota arises. What is the dose to organisms of natural populations submerged in water ma inta ined at the (MPC) $)_{w}$ or some fraction of the (MPC) $)_{w}$ for individual radionuclides? Would these dose rates be expected to result in detectable biological effects to aquatic organisms over a period of time? The accompanying tabulation (Table 1) shows the results of calculating the yearly dose rates at the surface of an organism submerged continuously in water containing various radionuclides ma inta ined at the $(\mathrm{MPC})_{\mathrm{w}}$ for the general human population. This is a totally hypothetical exposure condition used here to illustrate in general terms exposure levels to aquatic arganisms under these exposure conditions. The purpose of this calculation is merely to serve as a bas is for comparison with actual experimental dose response data cited later in this paper. In actual practice, the limit used currently around nuclear power stations of $10^{-6} \mu \mathrm{Ci} / \mathrm{cc}(1 \mathrm{pCi} / \mathrm{cc})$ is one to several orders of magnitude lower than the MPC's for the individual radionuclides used to derive this table. In assessing the effect of low doses of ionizing radiation, soph isticated means of detection must be used and sensitive biological endpo ints are necessary as criteria for ascertaining radiation damage. In experimental practice when dose rates are lowered to 1 rad per day or less, the number of factors affecting the organ ism are sufficient to mask any effects that might be present. Such commonly used endpo ints as survivorship, fecundity, growth, development, and susceptibility to infection have not as yet been shown to be unequivocally affected by such low dose rates. Evaluating the impoct of doses of less than 1 rad per day on 
TABLE I. Calculated Annual Submersion Dose Rates $(\beta+\gamma)$ from Water Maintained at the Occupational (MPC) $)_{w}$ for a 168 Hour Week $\times 1 / 30$. Organisms would have to live continuously in these waters to achieve these doses.

Calculated Dose Rates for Submission in Water Maintained at the (MPC) $)_{w} \times 1 / 30^{\circ}$

Radionuclide $\mathrm{rad} / \mathrm{yr}$

Cobalt -60 .797

Manganese -54 .526

Chromium-51 .377

Zinc -65 .342

Barium -140 .0871

Strontium-89 .0658

Cesium-137 - Barium-137M .0596

bodine -131 .0391

Cerium-144 - Praseodymium-144 .0173

Ruthenium-106 - Rhodium-106 .00625

Strontium -90 .000236

"The (MPC) $)_{W}$ for cont inuous occupational exposure to the critical organ of man for each radionuclide was multiplied by $1 / 30$ to apply to the general population. 
on organisms and populations under field conditions is a challenge of considerable magnitude.

Very few studies have been made on natural populations exposed to chronic radiation higher than background. The sal ivary chromosomes of the larvae of Chironomus tentans which inhabit the radioactively contam inated bottom sediments of the White Oak Creek and White Oak Lake at Oak Ridge National Laboratory were analyzed for five years for chromosomal aberrations $[1,2,3]$. Calculations and measurements of the absorbed dose for the larvae living in the sediments gave values of 230-240 rad/yr or approximately 1000 times background for the area. Over 130 generations had been exposed to this or greater dose rates during the previous 22 years. Seventeen different aberrations were observed in the irradiated population while only six different aberrations were observed in the non-irradiated population; all six of these inversions were found in each population more than once and three occurred at relatively high frequency. Eleven aberrations -- ten inversions and one deletion -- werc observed only once except for one inversion, which was found five times in two collections from one site and was probably the result of one event [4]. The frequencies of these unique aberrations, found only in the irradiated population, were very low when compared with the frequencies of the endemic inversions. Blaylosik concluded that the occurrence of new aberrations in the contam inated area was increased by the high background radiation and that these new aberrations were rapidly el im inated by selection or genetic drift. If all new mutations and chromosome aberrations are considered to be deleterious, these findings could be construed as harmful; on the other hand, the populations in this irradiated area show no sign of detrimental effects using population numbers and reproductive capability as criteria under dose rates much higher than those that would be obta ined under present guidelines of release. Blaylock also found there was no difference between the irradiated and control populations with respect to the ir chromosomal polymorphism as evidenced in the endemic inversions. Therefore, he concluded that the chronic environmental radiation which was capable of producing a detectable increase of new chromosomal aberrations was not affecting the frequencies of the endemic inversions in the populations of White Oak Creek and White Oak Lake.

This radioactive habitat was also the site for another series of investigations by Blaylock [5]. In this case the natural population investigated was the hardy, highly adaptable mosquito fish, Gambusia affin is affinis. Approximately one huncted generations of fish have lived in this area since the first release of radioactive waste effluents. In th is investigation, another parameter of population fitness, fecundity -- or the number of offspring per female -- was considered since laboratory studies have shown that it can be influenced by ionizing radiation. These fish lived in a shallow portion of the lake where the sediments conta ined appreciable quantities of $137 \mathrm{Cs}_{\mathrm{s}} 106 \mathrm{Ru}_{\mathrm{U}}, 60 \mathrm{Co}, 90 \mathrm{~s}$, $65 \mathrm{Zn}$. Based on measurements and calculations these fish were exposed to approximately 1 ! rads/day external gamma radiation and $1.75 \mathrm{rads} /$ year from internal beta rudiation.

The most striking finding of this study, however, was the fact that the irradiated populations had a highly significant greater fecundity than the control population. In $h$ is paper Blaylock marshals evidence which supports the idea that irradiation can increase the fitness of organisms. These data support the hypothesis that radiation induced 
mutations, most of which would be deleterious in the homozygous condition, produce sufficient cumulative effects in the heterozygous condition to more than counterbalance induced dominant deleterious mutations. Apporently, under certain conditions, genetic variability resulting from radiation induced mutations can improve the fitness of organisms. Natural selection operating on a population with increased genetic variability results in an increased rate of evolution of the population and in its adaptation to environmental factors.

The increased fecundity of the female in the Gombusia population in White Oak Lake may be an adjustment to the chronic environmental radiation. An increased mortality of embryos that could be attributed to ionizing radiation was also found in this population. In this respect radiation would be analogous to an environmental factor that increases mortality. Another effect of radiation would be the increased genetic variability resulting from radiation-induced mutations. This would increase the rate of evolution and speed up the odjustment of the population to the increased mortal ity. However, this would not occur without some expense to the populatisn. Many genetic combinations would be selected aga inst and the individuals el iminated. In populations with a relatively short life cycle, such as fish and insects, where overproduction of young is the rule and selection is severe, the population level could be maintained in spite of the alimination of many individuals.

Similar findings were recently found by Cooley [6] in a study of the snail (Physa heterostropha) populations which inhabit radioactive waste seeps in the disposal area of Oak Ridge National Laboratory. These populations are excosed to a calculated dose rate of $0.65 \mathrm{rad} / \mathrm{day}$. This population had not developed resistance to ioniz ing radiation, based on laboratory experiments employing acute gamma radiation. A comparison of reproduction of snails from the irradiated population and snails from a control population showed that the irradiated snails had a significontly decreased production of egg capsules and a significantly increased number of eggs per capsule. Cooley suggests that the decreased capsule production was compensoted for by the increased number of egs per capeule, thus preventing a reduced level of fecundity. Selection pressure in the seep habitat would be for those indivituals that would contribute the most to the overall fitness of the population. Under these conditions the compensations of increased eggs per capsule would be advantageous to the entire population.

At the University of Washington, Professor Loren Donaldson has had underway a long-term study of the effect of chronic low level gamma radiation on the chinook salmon (Oncorhynchus tshawytscha) $[7,8,9]$. In these experiments eggs and alevins were exposed to rates of $0.5,1.0,2.5$, or $5.0 \mathrm{r} /$ day beginning immediately after fertilization until the yolk is absorbed and the young fish are completely formed, a period of 80-100 days, depending on water temperature. The fish from the exposed lots and a like number from the control group were fed for a period of about 90 days before being released to migrate to the sea. In the ocean the young fish must compete in a natural environment that presents many hazards. Upon return from the sea, the adult fish and the ir progeny are subjected to detailed study for all possible effects. 
The results of this series of long-term experiments, with numbers of fish ranging from 96, 000 to 256,000 per experiment, have given no indication that these high exposure rates are injur ious to the fish. Irradiations at these early life stages have not caused significant mortality or retardation of growth in either smolts or returning spawners, or in fecundity. In fact, Donaldson and his co-workers report that at the lowest exposure rate of $0.5 \mathrm{r} /$ day -- an exposure rate which is 105 times greater than background $(0.01-.02 \mathrm{mr} / \mathrm{hr})$-- the irradiation stock returned in greater numbers and produced a greater total of viable eggs than the controls.

The effects of ${ }^{65} \mathrm{Zn},{ }^{51} \mathrm{Cr}$, and ${ }^{90} \mathrm{Sr}-{ }^{90} \mathrm{Y}$ on the developments of oyster larvae were examined in a series of experiments by Nelson [10]. The biological entpoint was abnormal larvae -- defined as those larvae which had incompletely developod sholls 48 hours after fertilization. On the basis of these experiments, Wilson concluded that the concentration of ${ }^{90} \mathrm{~S}_{\mathrm{r}}-90 \mathrm{Y}$ necessary to produce abnormal oyster larvae (10 ${ }^{8}$ picocuries/liter) is ten million times greater than the maximum concentration of $90 \mathrm{~S} r$ in natural marine environments ( $10 \mathrm{pCi} /$ liter). The concentration of carrier-free $z$ inc -65 necessary to praduce an effect on oyster larvae in the first 48 hours after fartilization of the eggs is ten million times greater than the ${ }^{65} \mathrm{Zn}$ concentration in Willapa Bay. Concentrations of ${ }^{51} \mathrm{Cr}$ which caused demonstrable effects are 800,000 times greater or more than those reported in water collected between the mouth of the Columbia River and Willespa Bay in 1961, when all 8 Hanford production reactors were still in operation. Since then 6 of these have been shut down.

No review of this nature can forego mention of Russian work in this field, especially since Russians report effects at much lower concentrations of radionuclides than other workers. Russian emphasis has been placed on marine fish eggs. Polikarpov [11], who pioneered the studies in th is field, has reported on extensive studies with oggs on a large number of marine and freshwater species over the concentration range of $10^{-2}$ $\mathrm{pCi} /$ liter to $10^{8} \mathrm{pCi} /$ liter. They reported reduced hatching of the larvae and eorly mortality at concentrations of $10^{5} \mathrm{pCi} /$ liter and above, and the number of abnormalities increased significantly at concentrations of $10^{2} \mathrm{pCi} /$ liter and above with remurkable sonsistency.

British workers [12] did similar experiments with eggs of 2 fish spocies mointained from immediately after fertilization until hatching, in water contam inated with ${ }^{90} \mathrm{~S}_{\mathrm{S}}-9 \mathrm{OO}_{\mathrm{Y}}$ over a concentration range of $10^{2}$ to $10^{8} \mathrm{pCi} /$ liter. They did not observe any sign ificant increase in mortality or in the production of abnormal larvee.

Templeton, Nakatani and Held [12] point out that the particular significonce of the work from the U.S.S.R. is the unique concentration effect response repurted by Polikarpov in 1967. An increase in concentration over six orders of mognitude (from 200 to 200 million $\mathrm{pCi} /$ liter) no more than triples the abnormality prodiuction rote and only increases mortality five-fold. This result is inconsistent with the lineor hypothes is of dose response as well as with data from mony rodiobiological investigations.

Preliminary experiments of the effect of tritium on fish eggs are underway at Oak Ridge National Laboratory (ORNL) and at the University of Washington. At ORNL 
Blaylock [13] has subjected fertilized carp (Cyprinus carpio) eggs to various concentrations of tritiated water. The biological endpoint was hatchability which normally occurs at 72 hours when ma intained at $26^{\circ} \mathrm{C}$. Eggs either hatch or die. Since the embryonic stages are considered among the most sensitive stages of the life cycle to irradiation, th is was considered a useful method for testing the effect of tritiated water. An additional advantoge is that the oggs imbibe water and swell. Assuming no descrimination against tritium, the eggs would be exposed to both external and internal doses from tritium. The concentrations used ranged from $6.75 \times 10^{7}$ to $51.8 \times 10^{7} \mathrm{pCi} / \mathrm{cc}$. These concentrations delivered a 72 hours dose to the eggs and developing embryos of from 57 to 436 rads. Although the percent age of eggs that hatched is less in three of the concentrations than in the controls, statistical tests showed no sign ificant differencess between any of the doses and the controls.

At the University of Wash ington [14] hybrid trout eggs were exposed to tritiated water at concentrations ranging from $10^{9}$ to $10^{11} \mathrm{pCi} /$ liter of water. No significant differences between groups were observed. The investigators are repeating the experiments with a hundredfold increase in the highest concentration $\left(10^{3} \mathrm{pCi} /\right.$ liter $)$. These workers also tested the effects of tritiated seawater on spore germination and sporling development of the algae Padina japo inia Yamada. Effects on germ ination and subsequent growth were observed only at the highest concentrations of tritium used $\left(3 \times 10^{10}\right.$ $\mathrm{pCi} /$ liter). Admittedly, these tritium experiments have not followed up on any effects which might show up later after fresh eggs have hatched. Nevertheless, one should bear in mind that concentrations up to 100 million times greater than MPC levels showed no effects on fish eggs and that in algae effects showed at ten million times greater than MPC levels.

Much more data of this kind could be reported. All would tend, with the possible exception of Russian work, to show that the dose necessary to evoke an unequivocally detectable biological response is considerably greater than that resulting from MPC concentrations in the environment. The reason for this judgment lies in the fact that there undoubtedly would be other factors changing in the envirorment, or other substances added to the aquatic environment that may and undoubtedly will have an effect on the constituent organ isms. These substances (chemicals, nutrients, etc.) may modify the habitat and affect the constituent orgonisms present to the extent that it will be extremely difficult, using current mothodologies, to demonstrate effects that might result from the low levsls of radioactivity.

One might invoke special effects, or organisms with undefined or speciol roles in the ecosystem that makes them uniquely sensitive (and therefore the ecosystem aiso) to the low dose rates that $m$ ighir occur in the vicinity of nuclear power stations. The possibility exists that the radiosensitivity of orgen isms may be increased significantiy as a result of environmental interactions. Ecologists are always seeking some unusual effect, or a species with high sensitivity to ionizing radiation. So far they have not found any organisms which, with in an environmental context, have a radiosensitivity at the levels of release permitted under current standards. Research is continuing to include as many different kinds of organisms as possible from a variety of environments (habitats) 
in order to demonstrate and differentiate the effects of radiation within an environmental context.

\section{ENVIRONMENTAL FATE OF RADIONUCLIDES}

\section{Introduction}

Evaluation of the hazard to humans will require a coherent theory, as well as predictive mathematical models, of radionuc! ide cycling and fate in the environment $[15,16]$. limited data are available for various aspects of the biological uptake and translocation of radionuclides in segments of environmental cycles, especially those cycles (food choins) leading to man [17]. It is one matter to know that food chains are important but quite a different matter to quantify these complex chains for natural and agricultural ecosystems [18]. It is not that we lack soph isticated mathematical techniques (e.g., the comportment models of systems analysis) to develop predictive models of ecosystem processes, but rather that we have neither sufficiently detailed nor widely representative radioecological data with which to work.

Analogous to the food chain (source-pathway-receptor), the parameters required for modeling the biological transport of rodienuclides in the environment include (1) pathway identification, (2) assimilation at each link in the pathway, and (3) the furnover rates of radionuclides by the receptor organisms. The second and third factors will determine the net uptake rate and the eventual radionuclide concentration in organisms. Acute releases of radionuclides into the environment are followed by transient peaks of radioactivity along the food-cha in pathways [19]. Knowledge of these pathways, assimilation, and furnover rates of radionuclides are essential for prediction of timedependent concentrations in the biota. Chronic releases will result in stoody-state concentrations in the biota, and, in these instances, concentration factors can be used to approximate the eventual equilibrium levels of radioactivity.

\section{Uptake by Aquatic Organisms}

Aquatic organisms accumulate rodionuclides directly from the water through gills or epithalial tissues, assimilation from ingested food or by a combination of these two routes. The physical-chemical behovior of the elements in water appears to be an important factor in determining the mode of initial entry into the food chain. Sodium is readily soluble and is an element absorbed directly from water by gills of fish [20]. In turtles the oral and cloacal mucosoe are active exchange sites for socium [21]. Experimental evidence show ing the direct uptake of $\mathrm{C}_{0}, \mathrm{~S}_{r}$, and $\mathrm{L}_{i}$ is available, but with $\mathrm{C}_{0}$ and $\mathrm{Sr}$ there is also food chain uptake. Schiffman [22] concluded that uptake of $90 \mathrm{Sr}_{\mathrm{r}}$ from water was mora efficient than assimilation from food in rainbow trout. However, Ophel and Judd [23] observed that dietary levels of strontium significontly affected the strontium content of fish tissues. Accordingly, fish oating a strontium -rich diet would be expected to ma intain a higher body burden of strontium. The direct uptake of other ionic forms of radionucl ides does not appear to be quantitatively important. 
Physical absorption of colloidal or particulate forms of radionuclides onto food items is a major pathway for entry of most radionuclides into aquatic food chains. Algae have a large surface area for absorption and are an important link in the food chain. Some radionuclides such as ${ }^{95} \mathrm{Zr}$ will hydrol ize and form colloidal particles which absorb on algae or can be removed by filter feeding organisms [24]. Following sorption onto food items or filtration from water, food-chain movement determines the environmental pathway for such radionuclides as $65 \mathrm{Zn}, 32 \mathrm{p}, 144 \mathrm{C}_{\mathrm{e}},{ }^{3} 7_{\mathrm{Cs}},{ }^{3} 1_{\mathrm{I}}$, ${ }^{51} \mathrm{Cr}_{\mathrm{r}},{ }^{6} \mathrm{~S}_{\mathrm{r}},{ }^{64} \mathrm{Cu}_{\mathrm{C}}$ and ${ }^{76} \mathrm{As}_{\mathrm{s}}$. Thereafter, assimilatir $\mathrm{n}$ at each link in the food cha in is an important variable associated with the type of contaminated food consumed. Transfers of $137 C_{s}$ to fish are influenced significantly by the incorporation of sediments in food. Bluegills assimilate $69 \%$ of the ${ }^{137} \mathrm{Cs}$ in algae, $16 \%$ from Chironomus larvae and only $3 \%$ from detrifus [25]. A comparable decrease in assimilation of $34 C_{s}$ with increasing sediment content of food was observed with carp [26]. Chromium -51 is assimilated at the higher trophic levels in the Columbia River [27] but food-chain transfer was not observed in a marine amphipod [28]. Fish were not able to assimilate $144 \mathrm{C} e$ incorporated into the undigestable exoskeleton of prey [29]. Thus, the presence of metabolic sinks such as arthropod exoskeletons or molluse shells affects the transfer or radionuclides in food chains. Marine amphipods assimilate $65 \mathrm{Zn}(55.7 \%)$, ${ }^{46} \mathrm{Sr}$ (9.4\%) and $144 \mathrm{Ce}$ (6.2\%) from contam inated brine shrimp [28]. White crappie may assimilate $100 \%$ of the ingested $42 \mathrm{~K}$ fed in goldfish [30]. Fish size may also be a factor, since bluegills weighing $80-120 \mathrm{~g}$ assimilate $16 \%$ of the $137 \mathrm{Cs}$ ingested with Chironomus larvae while $18-20 \mathrm{~g}$ fish and $8-10 \mathrm{~g}$ fish assimilate $13 \%$ and $7.1 \%$ of the T37Cs, respectively [31]. While we are able to make some generalizations with respect to the movement of radionuclides in food chains, it is apparent that knowledge of specific pathways to man is necessary to assess poiential radiological hazards.

\section{Uptake by Terrestrial Organisms}

Among terrestrial invertebrates, assimilation is variable according to the nature of the food base. For detritus, where most of the soluble constituents have been leached and those rema in ing are largely incorporated into poorly digestible tissue structures, assimilation is lowest; ${ }^{134} \mathrm{Cs}_{\text {and }}{ }^{137} \mathrm{C}_{s}, 53$ to $65 \%$; $90 \mathrm{~S}_{\mathrm{r}}, 77 \%$; and ${ }^{47} \mathrm{Ca}, 69 \%$. Assimilation from dried meal is similarly low: ${ }^{131}$ I approximately $21 \%$ and $51 \mathrm{Cr}_{\mathrm{r}}$ approximately 5\%. Green foliage or similar herbaceous materials present a food base with an elemental content more readily available in the form of cellular constituents: ${ }^{134} \mathrm{Cs}_{s}$ and $137 \mathrm{Cs}_{s} 73$ to $94 \%$ ( $100 \%$ in sap-sucking aphids); $32 \mathrm{p}$, is 54 to $66 \%$; $86 \mathrm{Rb}$, $100 \%$; and $187 \mathrm{~W}$, approximately $100 \%$ in sap-sucking bugs. Predators feeding on flesh show even higher assimilation efficiencies; ${ }^{134} C_{s}$ and ${ }^{137} C_{s}, 79$ to $94 \%$; and ${ }^{47} \mathrm{Ca}_{\mathrm{a}}, 98 \%$. Assimilation from water is charcecteristically high: $22 \mathrm{Na} 80 \% ; 2 \mathrm{~K}, 97 \%$; $134 C_{s}, 73 \%$; and $187 \mathrm{~W}, 83 \%$. Ruthen ium $-106(30 \%)$ and $60 \mathrm{Co}(25 \%)$ are alements that are poorly assimilated, as are ${ }^{131}$ I and 51 Cr.

Uptake of elements by mammal ian tissues can occur via three routes: respiratory tract, skin, and gastro intestinal (GI) tract. Uptake by the latter route zormally is the most important in natural environments. Inhaled material may be absorbed directly by lung tissues or moved by ciliated epithelium to the esophagus and ingested. Skin is 
apparently of minor importance in admitting most elements, although tritium and deuterium from atmospheric water enter freely [32]. The lanthanide and actinide elements are poorly absorbed $(<i \%)$ through the $\mathrm{Gl}$ tract walls, and so are the elements Be, Sc, Ti, Cr, Ga, Ge, Y, Zr, Nb, Cd, In, and La [33]. The lighter elements from atomic number 1 through 19 (except for $\mathrm{Be}, \mathrm{Mg}$, and Al) are absorbed well (70 to 100\%), as are the elements $\mathrm{Se}, \mathrm{Br}, \mathrm{Kr}, \mathrm{Rb}, \mathrm{Mo}, \mathrm{l}, \mathrm{Xe}, \mathrm{Cs}, \mathrm{Hg}$, At, and Fr. The remaining elements have intermediate absorbabilities. Considerable diversity of radionuclide concentrations in mammalian herbivores and carnivores also should be expected because of varied feeding habits, such as seasonal changes in diet and selective feeding on tissues [34].

Comparative data on biologica! holf-lives of many elements are not available for a large number of manmal ian species, but considerable information is available for various isotopes in species ranging in size from $8 \mathrm{~g}$ to about $900 \mathrm{~kg}$. Mbst of the elements with short biological half-lives concentrare in soft tissues, whereas the remainder with extended biological half-lives have long residence times in slowly metabolizing or inert tissues such as bone, teeth, or hair. Relatively short biological half-lives for cesium have been described for domesticated rabbits and species in the families Bovidae, Cervidae, and Suidae in the Artiodactyla. Similar consistently low values for iodine retention occur in these same groups. It appears that turnover of these elements (and perhaps others) may differ among mammal families. Practically nothing is known about radionuclide metabolism in about 10 of the 13 metazoan phyla, and much more experimental information is needed.

\section{Environmental Systems Analysis for Dose Estimation}

There is at present no overall predictive methodology to ascertain expected to tal doses to populations from radionuclides released to the environment and subsequently moving in a variety of exposure pathways. Such a methodology should make possible the comparison of actual doses to human populations with radiation standards and guidelines. In a future nuclear power economy, if current public attitudes toward radioactive releases continue to prevail, it will be necessary to know in detail the expected dose comm itments to segments of the human population.

Environmental systems analysis is an approach which offers considerable promise as a methodology for predieting doses from multiple sources (power reactors), routine or accidental releases, or other sources of radionuclides that $m$ ight be moved through a variety of environmental pathways. Systems ecologists usually begin by formulating an a priori couplad compartment flow diagram based on what ever information is available. This is the first of several steps in the hierarchy of modeling techniques that inight be employed. The initial models probabiy will be composed of relatively fow compartments, will have constant transfer coefficients, and will not incorporate probability functions. As the body of data on each subsystem develops, the in itially simple modals are updated and modifications are incorporated until predictions are checked to be with in the desired accuracy. Evenisually, sufficient information may become availabie to use nonl inear functions and probability distributions. One unique feature about 
systems modeling is that each step can have a feedback loop which helps to improve the accuracy of the model, so that as modeling continues, the accuracy of predictions are expected to improve.

The advantages of environmental systems analysis are not un ique to this particular field; they can be compared to the widely accepted use of systems analys is to study auclear reactor dymanics $[35,36]$, and indeed, environmental system analys is for reacter hazards analysis should be thought of as an outgrowth or a logical extension of this work. After initial data have been procured (engineering, chemical, or ecological), much the same systems analys is procedures are used for analysis.

If an off site central data processing center is used to implement the mathematical models, real time data on meteorology, stream flow, and radioactivity concentrations in effluents could be related to the processing center vio telephone lines. Most other major types of data used in the models would not have such short time constants, and may require only secsonal or periodic updating.

Although environmental systems analysis is becoming widely recognized as a tool of considerable potential for predicting the movement of substances and energy in natural systems, there have been few demonstrations of its practical value for predicting the intake of radionuclides by man. Kaye and Ball [37] demonstrated the use of two general purpose systems analysis computer codes for predicting concentrations of $137 \mathrm{Cs}_{\mathrm{s}}$ in bananas of a hypothetical banana plantation. One code utilized an exponential matrix method to solve the differential equation [38] while the other utilized a frequency response technique with sensitivity analyses calculated for a large combination of transfer coefficients and radionuclide concentrations [39]. Environmental systems modeling, was used in the Radiological Safety Feasibility Study of constructing a sea-level canal through Panama or Colombia with nuclear explosives $[40,41]$. This application of systems analysis attempted to predict concentrations of radioactivity in foods and beverages that might be consumed by man after reentry to a contam inated exclusion zone. Doses were estimated as a function of age and popu lation group and compared to radiation standards of recognized authorities [42].

\section{Thermal Effects Considerations}

Temperature is one of the most important physical factors affecting ecological processes. Its change by thermal generating stations should, therefore, be considered seriosisly. In an established ecosystem, rates of operating processes are generally increased until an upper limit for each is reached. Thereafter, continued temperature rise invokes precipitous slecline. An aquatic ecosystem has a multitude of individual processes operating simultaneously at several levels of organization, molecular, cellular, organism, population and community. The summation of the individual processes yields specific, and often seasonally variable, upper and lower temperature requirements that must not be exceeded if the ecosystem is to rema in biologically productive. In order to design and locate thermal power plants which utilize natural water for cooling without disrupting ecological systems, we must know these requirements. In lieu of adequate knowledge, assumptions by regulatory agencies may restrict 
optimal use of aquatic environments in some cases, or fail to protect the important species in others.

Thermal power plants also introduce new processes, or additional affectors of existing processes, into the aquatic ecosystem used as sources and receivers of cooling water. We must understand these new processes and their location in the power plant cooling system or in the heat disposal sequence outside of a power plant. We must learn the relationships between these new processes and the diverse ecological communities (marine, estuarine, riverine, lacustrine, etc.) that reside in potential cooling water supplies. Through appropriate plant siting and design, the operation of some of these necessary processes (e.g. thermal shock) can be engineered to affect few organisms or non-vital portions of the ecosystem, or the intensity of the process can be designed to be below detrimental levels for organisms. Pioper selection of alternative plant designs can reduce significantly the operation of other introduced processes (e.g., organic enrichment) once quantitative biological data are available.

An example will illustrate a process introduced to an aquatic system by a power plant and the contribution that quantitative ecological data can make toward reduction of detrimental effects.

The introduced process is thermal shock, occurring to small, planktonic or pelagic organisms drawn with the cooling water through the condensers (Fig. 1). These small organisms are often vital links in food chains, or immature forms of important fish or invertebrates. The power plant can act as a large, artificial predator on these populations. The thermal shock process, however, is a necessary part of the cool ing operation, i.e., transfer of heat rapidly from condensers to the water passing through it. Entrained organ isms experience an abrupt $r$ ise in temperature within the few seconds of condenser passage. This higher temperature is mainta ined through the outlet works, which may involve several minutes duration in a long discharge canal. The temperature then falls with in the mixing zone in the receiving water until the final temperature approaches the ambient water temperature.

Summaries of temperature elevations through condensers at operating stations vary, but generally about 8 degC is noted $[43,44]$. A survey of 61 power reactor designs filed with the U. S. Atomic Energy Commission revealed an average rise of 10.8 degC and a range of $5.6 \mathrm{deg} C$ to $18.0 \mathrm{deg} C$.

Thermal resistance times describe quantitatively the responses of aquatic organ isms to thermal shock in laboratory experiments. Above an incipient lethal temperature, characteristic of each species and its thermal history, the organ ism survives for a period of time that varies inversely with temperature. During the warmor seasons, temperature elevations in condensers may raise organisms above the incipient lethal level and thus to temperatures that are potentially directly lethal. Information on resistance times for affected species and accurate predictions of the temperature patterñ allows quantitative prediction of the likelihood of mortality during the period of temperature elevation. Resistance times for equilibrium loss or for succeptibility to predation allow quantitative 


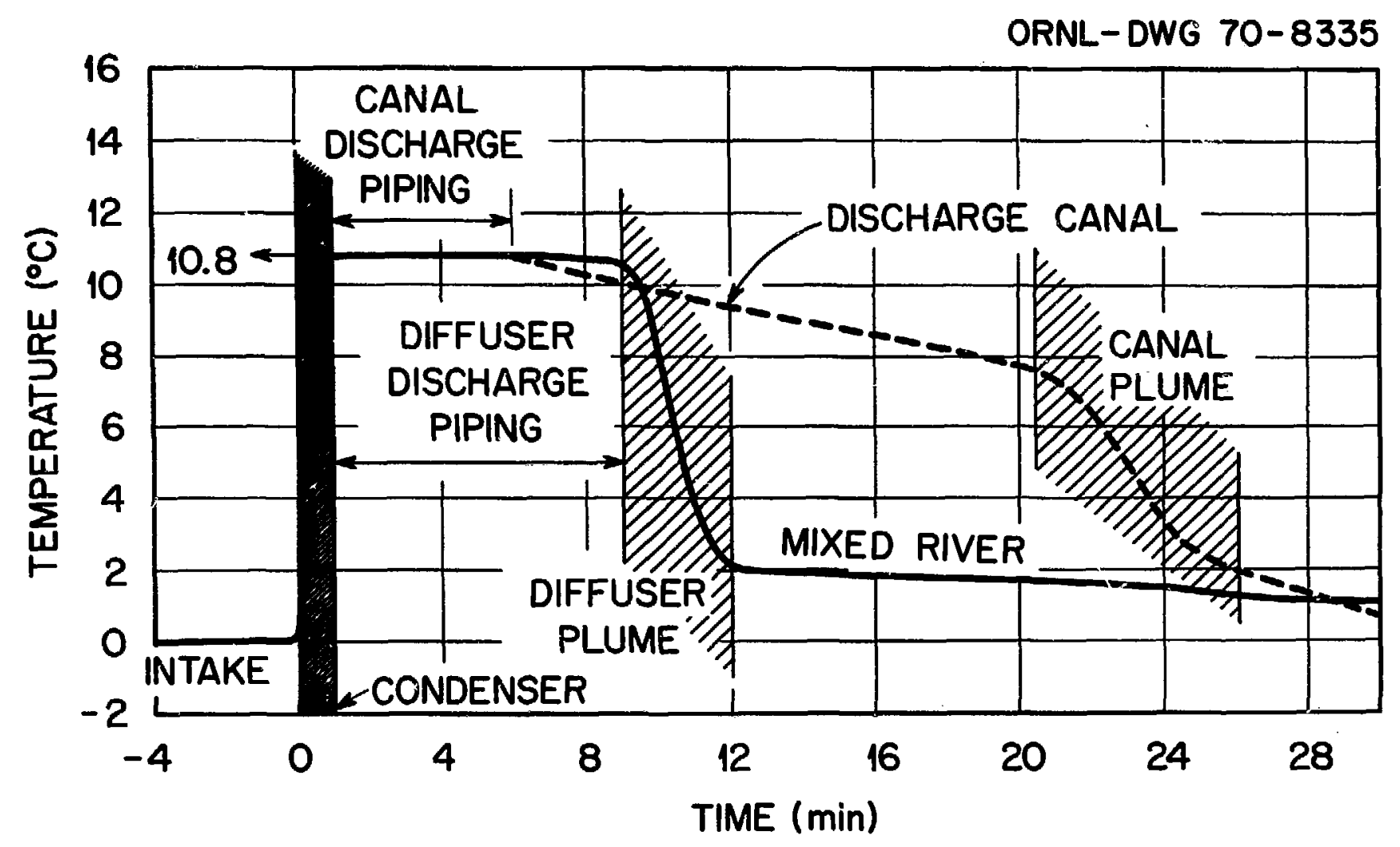

FIG. 1. Hypothetical time-courses of acute thermal shock to organ isms entra ined in condenser cooling water and discharged by diffuser or via a discharge canal. 
prediction of these indirectly lethal effects as well as direct lethality [45]. With these predictions defining boundary conditions of temperature rise and duration of exposure needed for survival, the thermal shock sequence of Fig. 1 can be modified through engineering design to minimize the detrimental effects.

Distributional data on entrainable organisms in the receiving water also can $\mathrm{mini}$ mize the effects of thermal shock on the aquatic community. Zooplankton orgarisms generally exhibit characteristic vertical zonation in lakes and estuaries, and this zonation process often changes diurnally. Power plant inlet structures can be designed to withdraw cool ing water at various alternative depths, a practice common in reservoir designs. Quantitative knowledge of biotic vertical zonation patterns at the proposed site, and timely application of this information to intake design can simply avo id entrain ing many organisms and thus reduce significantly the severity of thermal shock effects.

In addition to the ecological problems which result directly from thermal changes or plant operation, there are several possible indirect results of condenser cooling that merit serious analysis and study.

1) Chemical changes in cooling water accompany recirculation through cooling towers and cooling ponds. A concentration of salts and radionuclides, changes in $\mathrm{pH}$, and addition of biocides have been reported or anticipated [46]. All would have effects on biota of the recipient water body. Quantitative data on effects can contribute to minimizing them.

2) Reduction in water volume by cooling devices may lead to decreased river flows needed to ine inta in fishery resources. Careful site selection based in part on ecological data can avo id such instances.

3) Small temperature changes can interact with other constituents of water and modify uptake, turnover or toxic ity of these materials (including radionuclides and pesticides). Thus, food-chain transport of hazardous substances may be altered sufficiently to affect predicted exposures to mildlife and man. Quantitative information for thermal effects on such transport should be considered in hazard evaluations.

These are but excmples of important ecological considerations in siting therma! discharges. Ecological effects, however, need not be the obstacle that precipitatas an energy cris is [47]. Quantitative ecological data, suitable for predictive modeling, obtained for processes shown to be pertinent to power plant design and operation can allow for selection of good sites, design of safe discharges, and operation of nuclear power stations without detriment to balanced ecosystems. 


\section{REFERENCES}

[1] BLAYLOCK, B.G., "Chromosomal aberrations in a natural population of Chironomus tentans exposed to chronic low-level radiation," Evolution 193 (1965) 421-429.

[2] BLAYLOCK, B.G., "Chromosomal polymorphism in irradiated natural populations of Chironomus," Genetics 531 (1966o) 131-136.

[3] BLAYLOCK, B.G., "Cytogenetic study of a natural population of Chironomus inhabiting an area contam inated by radioactive waste, " In DisposaT of radioactive Wastes into Seas, Oceans, and Surface Waters, International Atomic Energy Agency, Vienna (1966b).

[4] BLAYLOCK, 1965, supra.

[5] BLAYLOCK, B.G., "The fecundity of a Gambusia affinis affin is population exposed to chronic environmental radiation," Rodiation Research 371 (1969) 108-117.

[6] COOLEY, J.M., "Effects of chronic irradiation and temperature on populations of the aquatic snail Physa heterostropha, "Ph.D. Thesis, University of Tennessee, Knoxville, Tennessee (August 1970).

[7] DONALDSON, L.R., BONHAM, K., EAGLETON, J.G. and CASTLE, P., "Chronic irradiation of chinook solmon," Research in Fisheries, Contr. No. 300, College of Fisheries, University of Wash ington, Seattle (1969) 52-53.

[8] BONHAM, K. and DONALDSON, L.R., "Low level chronic irradiation of salmon eggs and alevins," In Disposal of Radioactive Wastes into Seas, Oceans, and Surface Waters, International Atomic Energy Agency, Vienna (1960).

[9] DONALDSON, L.R. and BONHAM, K., "Effects of low-level chronic irradiation of chinook and coho salmon eggs and alevins," Trans. Amer. Fish Soc. 93 (1964) $333-341$.

[10] NELSON, V.A., "Effects of Strontium-90 - Yttrium-90, Zinc-65, and Chromium-51 on the larvae of the Pacific oyster, Crassostrea gigas, "M.S. Thesis, University of Washington (1968).

[11] POLIKARPOV, G.G., "Radioecology of aquatic organisms," Transl. from Russian by Scripta Technica Ltd., English translation edited by V. Schultz and A. W. Klement, Jr., Now York: Reinhold Publ. Co. (1966) 314 pp.

[12] TEMPLETON, W.L., NAKATANI, R.E and HELD, EDWARD, "Radiation effects in: Radioactivity in the marine environment, " A report in preparation by the National Academy of Sciences, Washington, D. C. (1970). 
[13] BLAYLOCK, B.G., "The hatchability of carp eggs in different concentrations of tritiated water," In Ann. Prog. Rept. Ecological Sciences Division, Oak Ridge National Lab. (in press).

[14] HELD, E.E., BALTZO, R.M., BEASLEY, T.M., ERICKSON, R.C. and SEYMOUR, A.H., "Laboratory of Radiation Ecology (Effects of Tritium)," In Research in Fisheries, Contr. No. 300, College of Fisheries, University of Washington, Seattle (1969) 53-54.

[15] OLSON, J.S. and AUERBACH, S.I., "Biological contam ination and dispersal of radioactive wastes," Nucl. Safety $I 3$ (March 1960) 62-65.

[16] REICHLE, D.E., DUNAWAY, P.B. and NELSON, D.J., "Turnover and concentration of radionuclides in food chains, " Nucl. Safety 111 (Jan-Feb 1970).

[17] WITKAMP, M., "Biological uptake of radionuclides," Nucl. Safety 222 (1960) 65-69.

[18] AUERBACH, S.l., "Radionucl ide cycling: Current status and future needs," Health Phys. 11 (1965) 1355-1361.

[19] CROSSLEY, D.A., Jr. and REICHLE, D.E., "Analysis of transient behovior in insect food chains," BioScience 194 (1969) $341-343$.

[20] KROGH, A., Osmotic regulation in aquatic animals, Cambridge Univ. Press, New York (1939).

[21] DUNSON, W.A., "Conceniration of sodium by freshwater turtles, "In Symposium on Radioecology, D. J. Nelson and F. C. Evans (Eds.), USAEC Report CONF670503 (1969) 191-197.

[22] SCHIFFMAN, R.H., "The uptake of strontium from diet and water by rainbow trout, " USAEC Report HW-SA-1997 (1960).

[23] OPHEL, I.L. and JUDD, J.M, "Strontium-calcium relationships in aquatic food chains," In Symposium on Radioecology, D. J. Nelson and F. C. Evans (Eds.), USAEC Report CONF-670503 (1969) 221-225.

[24] HELD, E.E., "Some aspects of the biology of Zirconium-95, " In Radioecology, V. Schultz and A. W. Klement, Jr. (Eds.), Reinhold, New York (1963) 577-579.

[25] KOLEHMAINEN, S.E, and NELSON, D.J., "The balances of ${ }^{137} C_{s}$, stable cesium, and the feeding rates of bluegill (Lepomis macrochirus Raf.) in White Oak Lake, " USAEC Report ORNL-4445 (196\%).

[26] KEVERN, N,R., "Feeding rate of carp estimated by a radioisotopic method, " Trans. Amer. Fish Soc. 95 (1966) $363-371$. 
[27] DAVIS, J.J. and FOSTER, R.F., "Bioaccumulation of radioisotopes through aquatic food cha ins," Ecology 39 (1958) 530-535.

[28] CROSS, F.A., DEAN, J.M., and OSTERBERG,. C.L., "The effect of temperature, sediment and foeding on the behavior of four radionuclides in a marine benthic amphipod," In Symposium on Radioecology, D. J. Neison and F. C. Evans (Eds.), USAEC Report CONF-670503 (1969) 450-462.

[29] BAPTIST, J.P. and HOSS, D.E., "Accumulation and retention of radionuclides in fish, " U.S. Fish and Wildl. Circ. 204 (1965).

[30] NELSON, D.J., "Cesium, cesium-137 and potassium concentrations in white crappie and other Clinch River fish, "In Symposium on Radioecology, D. J. Nelson and F. C. Evans (Eds.), USAEC Report CONF-670503 (1969) 240-248.

[31] KOLEHMAINEN, S.E., "The balance of ${ }^{137} C_{s}$, stable cesium, and the feeding rates of bluegill (Lepom is macrochirus Raf.) in White Oak Lake, "Ph.D. Thesis, University of Tennessee, Knoxville, Tennessee (1969).

[32] LANGHAM, W.H., "Radio isotope absorption and methods of el imination: Relative significance of portals of entry, " in: Radio isotopes in the Biosphere, R. S. Caldecott and L. A. Snyder (Eds.), University of Minnesota, Minneapolis (1960) 489-513.

[33] International Commission on Rodiological Protection, Report of Committee II on Permissible Dose for Internal Radiation, ICRP Publication 2, Pergamon Press Ltd., Oxford (1959).

[34] FRENCH, N.R., "Comparison of radioisotope assimilation by granivorous and herbivorous mammals," in: Radioecological Concentration Processes, Proceedings of an International Symposium held in Stockholm, April 26-29, 1966, Bertil Aberg and Frank P. Hungate (Eds.), Pergamon Press, Inc., New York (1967) 665-673.

[35] BALL, S.J. and KERLIN, T.W., "Stability analysis of the Molten-Salt Reactor experiment," ORNL-TM-1070 (December 1965).

[36] KERLIN, T.W. and BALL, S.J., "Experimental dynamic analysis of the MoltenSalt Reactor experiment," ORNL-TM-1647 (October 1966).

[37] KAYE, S.V. and BALL, S. J., "Systems analysis of a coupled compartment model for radionucl ide transfer in a tropical environment," In Proceodings of the Second National Symposium on Radioecology, D. J. Nelson and F. C. Evans (Eds.), USAEC Report CONF-670503 (1969) 731-739.

[38] BALL, S.J. and ADAMS, R.K., "MATEXP - A general purpose digital computer program for solving ordinary differential equations by the matrix exponential method, "ORNL-TM-1933 (August 1967). 
[39] KERLIN, T.W. and LUCIUS, J.L., "The SFR-3 Code - A Fortran program for calculating the frequency response of a multivariable system and its sensitivity to parameter changes, " ORNL-TM-1575 (June 1966).

[40] RAINES, G.E., BLOOM, S.G. and LEVIN, A.A., "Ecological models applied to radionuclide transfer in tropical ecosystems, "BioScience 19 (1969).

[41] MARTIN, W.E., RAINES, G.E., BLOOM, S.G. and LEVIN, A.A., "Ecological transfer mechanisms - terrestrial," Symposium on Public Healith Aspects of Peaceful Uses of Nuclear Explosives, Las Vegas, Nevada, April 7-11, 1969, SWRHL -82 (1969) 401-435.

[42] KAYE, S.V. and ROHWER, P.S., "Dose estimation studies related to proposed construction of an Atlantic Pacific interoceanic canal with nuclear explosives: Phase III, " ORNL-4579 (In Press).

[43] Water Resources Council, The Nation's Water Resources, U.S. Gov't. Printing Office, Washington, D. C. (1968).

[44] Water quality criteria for European freshwater fish - water temperature and inland fisheries, European Inland Fisheries Advisory Commission (EIFAC), Water Research 3 (1969) 645-662.

[45] COUTANT, C.C., "Temperature, reproduction and behavior, " Chesapeake Sci. 10 (1969) 261-274

[46] DAVIES, I., "Chemical changes in cooling water towers," Air and Water Pollut. Int. J. 10 (1966) 853-863.

[47] BOFFEY, P.M., "Energy crisis: Environmental issue exacerbates power supply problem," Science 168 (1970) 1554-1559. 


\section{FIGURE LEGEND}

Fig. 1. Hypothet ical time-courses of acute thermal shock to organ isms entra ined in condenser cool ing water and discharged by diffuser or via a discharge canal. 